\title{
Tuberculosis control in big cities and urban risk groups in the European Union: a consensus statement
}

N A van Hest ${ }^{1}$, R W Aldridge², G de Vries³, A Sandgren4, B Hauer5, A Hayward², W Arrazola de Oñate ${ }^{6}$, W Haas ${ }^{5}$, L R Codecasa7, J A Caylà ${ }^{8}$, A Story9, D Antoine ${ }^{10}$, A Gori ${ }^{11}$, L Quabeck ${ }^{12}$, J Jonsson ${ }^{13}$, M Wanlin $^{6}$, À Orcau ${ }^{8}$, A Rodes $^{14}$, M Dedicoat ${ }^{15}$, F Antoun $^{16}$, H van Deutekom ${ }^{17}$, S T Keizer ${ }^{17}$, I Abubakar (i.abubakar@ucl.ac.uk) ${ }^{18}$

1. Municipal Public Health Service Rotterdam-Rijnmond, Rotterdam, the Netherlands

2. University College of London, Department of Infection and Population Health, London, United Kingdom

3. KNCV Tuberculosis Foundation, The Hague, the Netherlands

4. European Centre for Disease Prevention and Control, Stockholm, Sweden

5. Robert Koch Institute, Berlin, Germany

6. Belgian Lung and Tuberculosis Association, Brussels, Belgium

7. Villa Marelli Regional TB Reference Centre, Niguarda Hospital, Milan, Italy

8. Public Health Agency of Barcelona, Barcelona, Spain

9. Find \& Treat, London, United Kingdom

10. Institut de Veille Sanitaire, Paris, France

11. TB PAN-NET, San Gerardo Hospital, University of Milan, Italy

12. Senate Department for Health, Berlin, Germany

13. Swedish Institute for Infectious Disease Control, Stockholm, Sweden

14. Catalan Health Department, Barcelona, Spain

15. Heart of England Hospital Chest Department, Birmingham, United Kingdom

16. Direction de l'Action Sociale de l'Enfance et de la Santé, Paris, France

17. Municipal Public Health Service Amsterdam, Amsterdam, The Netherlands

18. Public Health England and University College London, London, United Kingdom

In low-incidence countries in the European Union (EU), tuberculosis (TB) is concentrated in big cities, especially among certain urban high-risk groups including immigrants from TB high-incidence countries, homeless people, and those with a history of drug and alcohol misuse. Elimination of TB in European big cities requires control measures focused on multiple layers of the urban population. The particular complexities of major EU metropolises, for example high population density and social structure, create specific opportunities for transmission, but also enable targeted TB control interventions, not efficient in the general population, to be effective or cost effective. Lessons can be learnt from across the EU and this consensus statement on TB control in big cities and urban risk groups was prepared by a working group representing various EU big cities, brought together on the initiative of the European Centre for Disease Prevention and Control. The consensus statement describes general and specific social, educational, operational, organisational, legal and monitoring TB control interventions in EU big cities, as well as providing recommendations for big city TB control, based upon a conceptual TB transmission and control model.

The city can have as much reduction of preventable disease as it wishes to pay for. Public health is purchasable; within certain natural limitations a city can determine its own death rate.

Hermann Biggs, New York City Board of Health, Annual Report, 1915

\section{Background}

In low-incidence settings, which include most countries in the European Union (EU), tuberculosis (TB) is concentrated in big cities [1]. TB disproportionally affects certain, often overlapping, urban groups such as immigrants from TB high-incidence countries, homeless people, those with a history of drug and alcohol misuse, and people with a history of imprisonment [2-11]. Prevention and control of TB among these risk groups can be hampered by delayed diagnosis, onward transmission and poor treatment adherence [12-16]. For effective TB control, services in EU big cities should be acceptable, accessible, adequate, appropriate and geared towards the needs of urban risk groups. In the last decade, innovative TB control activities in EU big cities have been reported, including mobile digital chest X-ray screening [16-19], the employment of community health workers and peer-educators $[20,21]$, the use of mobile telephone-assisted or video-observed medication monitoring systems $[22,23]$, and the application of molecular epidemiology [24-27]. Systematic implementation of evidence-based and innovative approaches to improve early case finding, case holding and treatment completion in urban risk groups is urgently needed. Exchange of experience from different urban TB programmes in the EU will be key to achieving European TB control.

In February 2008, the European Centre for Disease Prevention and Control (ECDC) published the Framework Action Plan to fight tuberculosis in the European Union, 
providing proposals on what needed to be done in EU Member States to decrease the burden of TB [28]. The report recognises the concentration of TB in hard-tofind and hard-to-reach populations as one of the major challenges to TB control efforts across the EU and a key strategic element to reduce and eliminate TB. The EU action plan provides an opportunity to re-think urban TB control, specifically among vulnerable populations in the EU, and strengthen work through the exchange of experience, collaborative research, advocacy and cooperation. In this statement, we have summarised key evidence-based and expert opinion-led recommendations to inform the control of TB in big EU cities. For each recommendation, we have provided a brief background and a summary of the evidence available.

\section{Methods}

Informal contacts have existed between some big cities in the EU for over a decade. In October 2005, the Municipality of Paris organised a conference on metropolitan TB in Europe and the theme of TB in big cities was discussed at the $5^{\text {th }}$ European TB conference of the International Union Against Tuberculosis and Lung Disease (The Union) in Dubrovnik in 2009 [29]. During the Wolfheze Conference in 2010 [30], TB control in big cities in Europe featured in the programme for the first time and as a result of this meeting ECDC agreed to facilitate a workshop on urban TB control in December 2010. TB programme managers and TB control physicians from 10 big cities in eight EU countries attended the event in Stockholm and a working group gradually developed and generated this consensus statement on TB control in big cities and urban risk groups in the EU. The preliminary outcomes of a survey on the epidemiology of TB in big cities in the EU, as well as the process and the progress of the working group, were presented at the 2011 Wolfheze conference.

This consensus statement is based upon a conceptual model of structural and intermediate determinants (explained in the next section) of TB exposure, infection, disease and treatment [31], as well as interventions for TB control, especially in urban risk populations (Figure 1). Each section begins with a discussion of the background of general interventions and specific elements for TB control in big cities, and is then followed by agreed recommendations to achieve control of TB in EU cities. These recommendations are rated in accordance with the Scottish Intercollegiate Guidelines Network (SIGN) grading system (Table 1) [32]. Rating was perfomed by one of the authors (RWA) and subsequently ratified by the expert group Detailed information (checklists and critical appraisals) of the SIGN grading process is available on request from the corresponding author. The literature was selected by authors of the consensus statement in a non-systematic search. SIGN grading was developed for the assessment of evidence in clinical studies and is not necessarily directly applicable to all public health interventions. Therefore a risk-benefit, feasibility, cost-effectiveness and valueacceptability assessment of the recommendations has been added in addition to the SIGN grading (Table 2 ). Due to differences in the ratio of urban and national TB notification rates in EU Member States, this statement has concentrated on urban TB and control in lowincidence ( $\$ 20$ TB notifications/100,000 population) EU countries according to ECDC definition [33]. Although there is a great deal of relevant literature on urban TB and control outside the EU (especially in North America), for the purpose of this consensus statement the working group has focused on European publications when available.

\section{Social determinants and interventions}

\section{General background}

Social determinants, including structural (e.g. social, political, cultural and economic, health system) or intermediary (e.g. crowded living conditions) and the value of equity are major factors that influence health outcomes [34]. Wealth, health and infection inequalities that influence TB morbidity and mortality rates exist in and between EU countries [35-38], and are probably affected by economic crises [39].

\section{Social determinants and big cities}

Social determinants of TB are not exclusive to big cities but urbanisation and the associated poverty and overcrowding that is more commonly found in these locations, impact on the levels of TB [40]. In many big cities outside and inside the EU, socio-economically disadvantaged populations are more prevalent. This is putting all residents at greater risk of TB acquisition but is particularly increasing the risk among certain urban subpopulations [2, 41-43]. Immigrants, legal or undocumented, form a substantial proportion of big city populations in the EU and can contribute considerably to TB incidence $[24,42]$. Household overcrowding is often found in urban areas and is related to TB incidence $[42,44]$. Specific urban overcrowding has been described well in shelters for homeless people or facilities for people with drug misuse; two socially excluded groups that are often over-represented in EU big cities $[7,18,19,24]$. Social determinants are fundamental causes of TB in EU big cities and therefore solutions to control TB must tackle these issues [45]. A social outreach model of care has been advocated [46], including the role of a link worker who can enable integrated health and social care, by, for example, resolving issues related to health, housing need, welfare benefits and immigration, as well as clinical management issues [47].

\section{Recommendations}

Big city TB control programmes should:

1.1. advocate for sustained political commitment to emphasise the social determinants of health that put subgroups of the population at increased risk of TB;

1.2. investigate and monitor inequalities and socioeconomic deprivation and their links with TB in 
Conceptual model of structural and intermediate determinants of tuberculosis and areas of possible interventions, based on the natural history of tuberculosis from exposure through to infection and disease and treatment

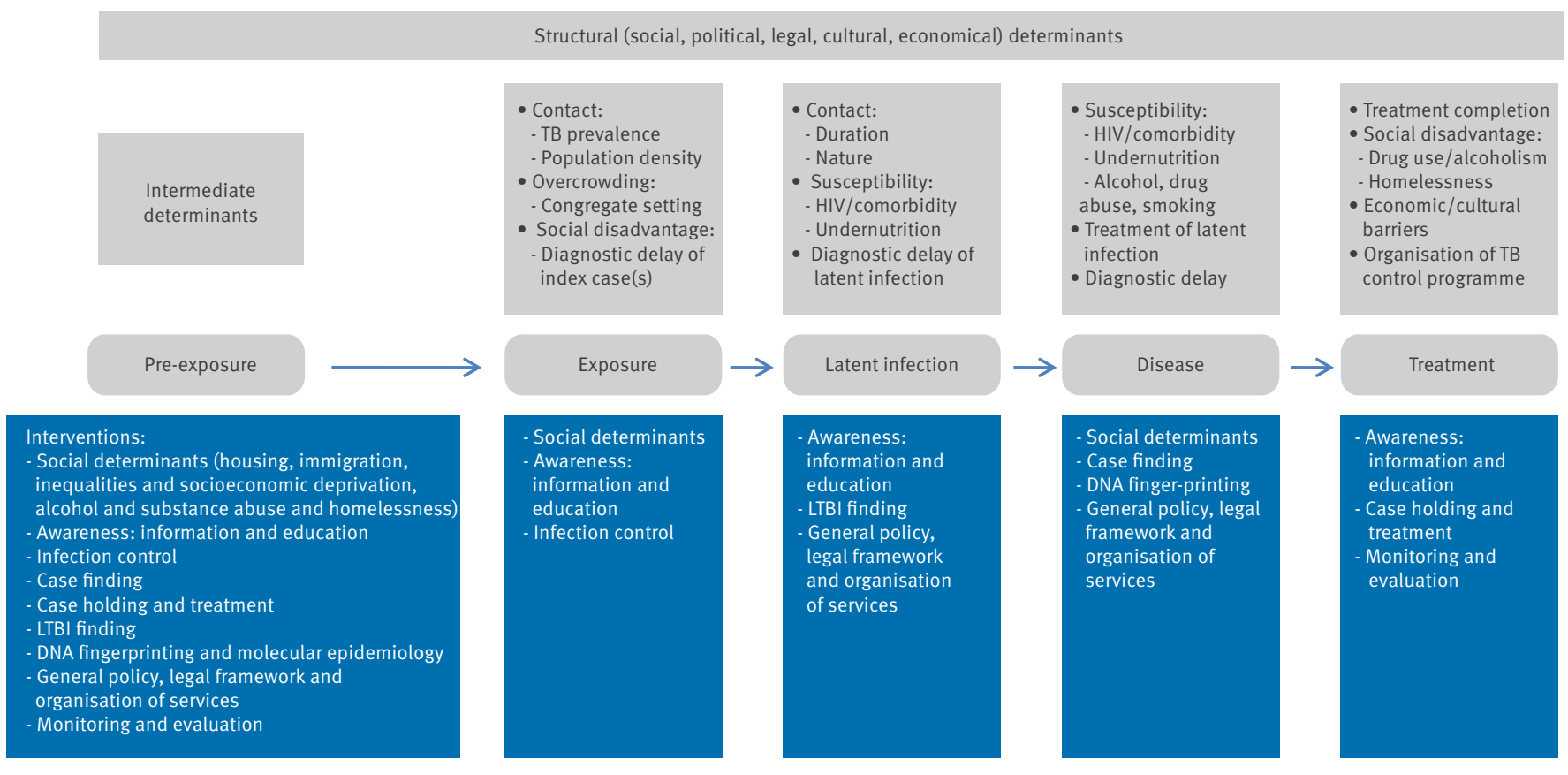

TB: tuberculosis; HIV: human immunodeficiency virus; LTBI: latent tuberculosis infection.

\section{TABLE 1}

Rating levels of the evidence used to make recommendations to inform tuberculosis control in big cities in the European Union, made in accordance with the Scottish Intercollegiate Guidelines Network (SIGN) grading system

\begin{tabular}{|c|c|c|c|}
\hline Rating & Study design & Special conditions & Level of evidence \\
\hline $1++$ & $\begin{array}{l}\text { High quality meta-analyses, systematic reviews of } \\
\text { RCTs, or RCTs with a very low risk of bias }\end{array}$ & If directly applicable to target population & \multirow{2}{*}{$A$} \\
\hline $1+$ & \multirow{2}{*}{$\begin{array}{l}\text { Well-conducted meta-analyses, systematic reviews, or } \\
\text { RCTs with a low risk of bias }\end{array}$} & $\begin{array}{l}\text { If directly applicable to target population } \\
\text { and overall consistency of results }\end{array}$ & \\
\hline $1++$ or $1+$ & & Extrapolated evidence & \multirow[b]{2}{*}{ B } \\
\hline \multirow[b]{2}{*}{$2++$} & $\begin{array}{l}\text { High quality systematic reviews of case control or } \\
\text { cohort or studies }\end{array}$ & $\begin{array}{l}\text { If directly applicable to target population } \\
\text { and overall consistency of results }\end{array}$ & \\
\hline & $\begin{array}{l}\text { High quality case control or cohort studies with a very } \\
\text { low risk of confounding or bias and a high probability } \\
\text { that the relationship is causal }\end{array}$ & Extrapolated evidence & \multirow{2}{*}{$C$} \\
\hline \multirow{2}{*}{$2+$} & \multirow{2}{*}{$\begin{array}{l}\text { Well-conducted case control or cohort studies with } \\
\text { a low risk of confounding or bias and a moderate } \\
\text { probability that the relationship is causal }\end{array}$} & $\begin{array}{l}\text { If directly applicable to target population } \\
\text { and overall consistency of results }\end{array}$ & \\
\hline & & Extrapolated evidence & \multirow{3}{*}{$D$} \\
\hline 3 & Non-analytic studies, e.g. case reports, case series & & \\
\hline 4 & Expert opinion & & \\
\hline 1- & $\begin{array}{l}\text { Meta-analyses, systematic reviews, or RCTs with a high } \\
\text { risk of bias }\end{array}$ & & \multirow[b]{2}{*}{$\begin{array}{l}\text { No supporting } \\
\text { evidence }\end{array}$} \\
\hline 2- & $\begin{array}{l}\text { Case control or cohort studies with a high risk of } \\
\text { confounding or bias and a significant risk that the } \\
\text { relationship is not causal }\end{array}$ & & \\
\hline
\end{tabular}

RCT: Randomised controlled trial 
TABLE 2

Assessment of the recommendations to inform tuberculosis control in big cities in the European Union, by evidence grading, risk-benefit, feasibility, cost-effectiveness and value-acceptability

\begin{tabular}{|c|c|c|c|c|c|}
\hline Recommendations & $\begin{array}{c}\text { Evidence } \\
\text { grading }\end{array}$ & Risk-benefit & Feasibility & Cost-effectiveness & Value-acceptability \\
\hline Recommendation 1.1 & $\mathrm{D}$ & Low/high & Possible & Unknown & Unknown/unknown \\
\hline Recommendation 1.2 & $\mathrm{D}$ & Low/high & Feasible & Unknown & Unknown/unknowna \\
\hline Recommendation 1.3 & $\mathrm{D}$ & Low/high & Possible & Unknown & Unknown/unknown ${ }^{a}$ \\
\hline Recommendation 1.4 & $\mathrm{D}$ & Low/high & Possible & Unknown & Unknown/unknown ${ }^{a}$ \\
\hline Recommendation 1.5 & $\mathrm{D}$ & Low/high & Possible & Unknown & Unknown/unknowna \\
\hline Recommendation 2.1 .1 & $\mathrm{D}$ & Low/high & Feasible & Unknown & Valued/acceptable \\
\hline Recommendation 2.1 .2 & $\mathrm{D}$ & Low/high & Feasible & Unknown & Valued/acceptable \\
\hline Recommendation 2.1.3 & $\mathrm{B}$ & Low/high & Feasible & Unknown & Valued/acceptable \\
\hline Recommendation 2.2 & $\mathrm{D}$ & Low/high & Feasible & Unknown & Valued/acceptable \\
\hline Recommendation 3.1 & $\mathrm{D}$ & Low/high & Possible & Unknown & Justified/acceptable ${ }^{b}$ \\
\hline Recommendation 4.1 & $\mathrm{C}$ & Low/high & Feasible & Possible & Valued/acceptable \\
\hline Recommendation 4.3 & $\mathrm{C}$ & Low/high & Feasible & Yes & Valued/acceptable \\
\hline Recommendation 4.4 & $\mathrm{D}$ & Low/high & Feasible & Unknown & Valued/acceptable \\
\hline Recommendation 5.1 & $\mathrm{D}$ & Low/high & Unknown & Unknown & Unknown \\
\hline Recommendation 5.2 & $\mathrm{D}$ & Low/high & Feasible & Unknown & Valued/acceptable \\
\hline Recommendation 5.3 & $\mathrm{D}$ & Low/high & Unknown & Unknown & Unknown \\
\hline Recommendation 5.4 & $\mathrm{D}$ & Low/high & Unknown & Unknown & Unknown \\
\hline Recommendation 5.5 & $\mathrm{D}$ & Low/high & Unknown & Unknown & Unknown \\
\hline Recommendation 6.1 & $\mathrm{D}$ & ${\text { Mediumf } / \text { high }^{g}}$ & Unknown & Yes $^{h}$ & Valued/acceptablei \\
\hline Recommendation 6.2 & $\mathrm{D}$ & 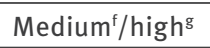 & Unknown & Yes $^{h}$ & Unknown \\
\hline Recommendation 6.3 & $\mathrm{D}$ & Mediumf $^{\text {fhighs }}$ & Unknown & Yes $^{h}$ & Valued/acceptable \\
\hline Recommendation 7.1 & $\mathrm{D}$ & Low/high & Feasible $^{j}$ & Unknown & Valued/acceptable \\
\hline Recommendation 8.1 & $\mathrm{D}$ & Low/high & Possible & Unknown & Unknown/unknown \\
\hline Recommendation 8.4 & $\mathrm{D}$ & Low/high & Possible & Unknown & Valued/acceptable \\
\hline Recommendation 8.5 & $\mathrm{D}$ & Medium $^{6} /$ high $^{7}$ & Possible & Unknown & Questioned/questioned \\
\hline Recommendation 8.6 & $\mathrm{D}$ & Low/high & Feasible & Unknown & Valued/acceptable \\
\hline Recommendation 9.1 & $\mathrm{D}$ & Low/high & Feasible & Unknown & Valued/acceptable \\
\hline Recommendation 9.2 & $\mathrm{D}$ & Low/high & Feasible & Unknown & Valued/acceptable \\
\hline Recommendation 9.3 & D & Low/unknown & Possible & Unknown & Valued/acceptable \\
\hline
\end{tabular}

a Acceptability of high cost interventions without clear immediate cost savings but with high cost savings in the future may be difficult in time of economic crisis and austerity.

b With education and information.

For latent TB infection screening, not for radiographic screening for disease.

d Legal framework may be needed.

e Value and acceptability will vary between urban TB risk groups.

$f$ Possible hepatotoxic and other adverse effects.

$\mathrm{g}$ High for the individual; unclear for public health.

h For immigrants.

Unclear for preventive treatment.

Cost can be prohibitive. 
order to intervene with a comprehensive public health approach $[28,37,38]$;

1.3. collaborate to promote suitable housing for homeless people in order to prevent transmission of TB and promote cure in this population [48-51];

1.4. provide access to social support for all vulnerable populations, irrespective of their status [52-54];

1.5. identify barriers and promote access to healthcare services for all those at risk of TB [21].

\section{Awareness: information and education interventions}

\section{General background}

Targeted provision of information to raise awareness among high-risk groups, in the form of leaflets or through the Internet, has been used for diseases other than TB, such as diabetes, HIV or breast cancer $[55,56]$. There is an increased drive to use raising awareness as a measure for TB control and to improve knowledge of TB among high-risk groups and the staff who work with them [57].

\section{Awareness and big cities}

Initiatives for raising awareness, such as active information and education strategies, should target urban TB risk groups, those working with urban TB risk groups, and healthcare professionals in urban areas $[11,23]$. To avoid stigmatisation, awareness of TB in risk groups in big cities can be improved on an opportunistic basis, for example, when a patient comes into contact with healthcare services for consultation or screening [11,58-61]. There is evidence from an educational intervention in London that promotion of screening in primary care can improve early identification of both active TB and latent TB infection (LTBI) [58].

\section{Recommendations}

Big city TB control programmes should:

2.1. implement a coordinated programme of education and training to raise and sustain awareness among affected risk groups and communities [11], frontline professionals working with high-risk groups $[11,21]$, and health and social care professionals, such as general practitioners $[11,58,62]$;

2.2. involve affected communities in the design and delivery of training and awareness raising programmes, taking into account cultural, language and literacy issues [11].

\section{Infection control in community settings}

\section{General background}

Infection control (IC) is an essential component of TB control and prevention and is included in the EU Standards of TB Care [63]. Shortcomings in IC have been major contributors to nosocomial outbreaks, including outbreaks in European TB reference centres [64]. Poor ventilation and overcrowding have been drivers of TB transmission in congregate settings such as homeless shelters, prisons and safe drug consumption facilities. General IC principles for healthcare settings can benefit these specific congregate venues [65]. New interest in IC has been awakened by the emergence of multidrug-resistant (MDR) and extensively drug-resistant (XDR) TB [66].

\section{Infection control in community settings and big cities}

Nosocomial transmission of TB in urban hospitals $[67,68]$, and effective IC measures in these healthcare settings [69], have been described in the EU. Transmission in hostels and shelters attended by risk groups, and prisons in big cities in the EU, have been suggested by conventional epidemiological studies [70] and strong evidence is supplied by molecular epidemiological studies using DNA fingerprint cluster analysis $[13,16,19,71-75]$. Congregate settings in big cities in the EU can implement hygienic measures (proper room ventilation and illumination, no overcrowding, cough hygiene) and organise TB awareness-raising activities. They can also implement administrative control activities (early guided referral of residents suspected of having TB for diagnosis and isolation), and motivate residents to participate in contact tracing or radiographic screening $[16,17,19]$. IC can also prevent TB infection or disease among healthcare workers and social workers in big cities $[13,65]$.

\section{Recommendations}

Big city TB control programmes should:

3.1. ensure implementation of IC measures in congregate settings used by urban high-risk groups (in addition to healthcare settings); these should follow national or international best practice guidelines [63].

\section{Case finding}

\section{General background}

TB control depends on early case finding and successful treatment [28]. Active case finding aims to identify those with TB who have not presented themselves to the healthcare system of their own accord, in order to reduce TB transmission [76]. Active case finding can be performed through symptom screening, questionnairebased screening (including risk factors), radiographic (e.g. chest X-ray) screening, sputum examination (e.g. microscopy, culture or rapid molecular techniques, including automated nucleic acid amplification tests). Reviews of contact tracing and immigrant screening in the EU [77,78], and effectiveness and cost-effectiveness of TB screening, have been published recently [10]. Disparities in active case finding in the EU have been described [79].

\section{Case finding and big cities}

The assumption that urban TB risk groups will present promptly, complete a diagnostic process that is sometimes difficult and prolonged, and take treatment lasting a minimum of six months is not a basis for effective TB control [45]. Active case finding among urban 
high-risk groups should be complemented by tailored strategies for completion of the diagnostic process and treatment. These strategies include low-threshold public health TB 'one-stop shops' with sufficient nursing, social and community healthcare worker staff, appropriate outpatient clinical follow-up or the ability to admit patients to general hospitals or modern-day sanatoria (also called tertiary TB treatment centres). Policies should be backed up by adequate legal frameworks for social support and protection and ensure knowledge about and facilitate access to healthcare services $[4,5,21,52,80]$. Controversies and unresolved issues in active TB case finding among urban hardto-reach groups have been recently addressed [10]. Contact tracing may not be feasible or effective for all urban risk groups, but can be in specific populations such as household or professional contacts $[5,13]$. Indiscriminate radiographic screening of immigrants is described as inefficient and not cost-effective $[10,76,79,81,82]$. However, some interventions that may not be effective when applied to the general population may be highly effective or cost-effective when targeted at specific urban high-risk groups, for example, homeless people and prisoners $[10,16,17,19$, 83-85]. Studies on longitudinal radiographic screening programmes for urban risk groups in the EU are limited but provide evidence that socially excluded and vulnerable urban risk groups can be reached $[18,86]$, and that TB transmission can be controlled $[16,19]$. The National Institue for National Health and Care Excellence (NICE) has recently published guidelines advising TB screening in hostels for homeless people and prisons [11,87]. ECDC and the European Monitoring Centre for Drugs and Drug Addiction (EMCDDA) have recently published guidance on prevention and control of infectious diseases in people who inject drugs [88].

\section{Recommendations}

Big city TB control programmes should:

4.1. implement and monitor contact tracing according to national guidelines and international best practice consensus $[21,78,89 \neg-91]$;

4.2. ensure that national guidelines for screening of immigrants are implemented [77];

4.3 consider targeted radiographic screening (e.g. mobile or static digital X-ray units) of urban highrisk groups, especially homeless people, people with drug and alcohol misuse, and prisoners $[11,16-19,83,85]$;

4.4 implement measures such as TB 'one-stop shops' to ensure that suspected TB cases in urban highrisk groups are not lost before confirmation or exclusion of disease $[11,21,63]$.

\section{Case holding and treatment}

\section{General background}

After case detection, TB control is founded on supporting patients to start and complete a long and occasionally complicated (e.g. due to adverse effects) course of treatment. The impact of poor compliance can be profound, both to the patient and to public health [31]. Treatment adherence is dependent on factors related both to the patient (e.g. language barriers or lifestyle factors) and to the provider (e.g. accessible, acceptable, adequate, appropriate and flexible services including treatment supervision and enhanced case management). Treatment supervision, such as directly observed therapy (DOT), requires adequate staffing levels based upon TB notification rates $[4,5,80,92]$. Enhanced case management requires multidisciplinary services such as specialist TB nurses, outreach social workers, TB link workers (or peer-support workers) with attention for any legal, social, housing or financial problems $[5,17,46,47]$. Conventional incentives and enablers, such as prepaid travel cards for public transport, can be used to increase adherence, as well as monetary incentives, which are controversial but have been demonstrated to be effective [93]. Innovative ways to increase adherence to TB treatment using modern technology should be explored as they have been in the field of human immunodeficiency virus (HIV) infections $[22,23,94,95]$. When patients are either too medically or socially complex to be treated in a general hospital or on an outpatient basis, modern-day sanatoria can be invaluable $[96,97]$. Cohort reviews are key to improving case management and have played a major role in increasing treatment completion rates $[7,98,99]$.

\section{Case holding and treatment and big cities}

Failure to attend appointments with medical or public health services is well-known among certain urban risk groups for TB $[4,15]$. For immigrants, factors such as legal, cultural, and language issues, socio-economic barriers and lack of knowledge about the healthcare system can result in taking the wrong medication or poor treatment adherence [100]. People who are homeless, or who have a history of drug or alcohol misuse, or of imprisonment, are all groups associated with poor adherence, and comprised $44 \%$ of cases lost to followup in London $[7,31,101]$. However, treatment completion can be very high among drug and alcohol misusers and homeless people in an adequate urban TB control programme with strict treatment supervision and potential mandatory isolation [16]. For case holding in big cities, the TB control programme should closely cooperate with related services, such as HIV programmes [63], services for people with a history of drug and alcohol misuse [88], prison services [102], asylum seeker services [53], and services for homeless people $[13,16]$. The use of supervised housing for homeless TB patients appears to be both effective and cost-effective $[49,50]$. Outreach services can reduce hospitalisation and therefore costs $[103,104]$. Establishment of TB link workers can reduce failed attendance through use of telephones, SMS reminders or accompanied referrals $[17,22,23,46,47]$. Specific attention is needed for undocumented migrants to ensure completion of treatment [52].

\section{Recommendations}

Big city TB control programmes should: 
5.1. be complemented with social support systems directed towards the different risk groups, such as accommodation for homeless people or access to methadone replacement programs for people with drug misuse $[11,49,50,88]$;

5.2. identify patients who can benefit from DOT prior to treatment, with DOT being considered for patients with risk factors for non-adherence as part of a patient-centred care plan $[11,63,105,106]$;

5.3. provide low-threshold and accessible services that are staffed according to TB notification rate and establish partnerships with other relevant healthcare providers working with groups at high risk of $T B$, to support treatment continuity $[4,5,11,47,63,107,108]$;

5.4. consider provision of incentives and enablers, peer-support workers and modern information technology to improve treatment adherence and outcomes [11,17,22,23,46,47,93,94];

5.5. be supported by EU healthcare regulation allowing undocumented migrants to complete TB treatment in the country of diagnosis [52-54].

\section{Latent tuberculosis infection}

\section{General background}

The primary aim of screening for LTBI is to prevent TB disease. Aspects of active screening for LTBI in the EU [76], a European consensus statement on TB contact tracing [78], ECDC guidance on the use of interferongamma release assay (IGRA) for diagnosis of LTBI [109], and controversies and unresolved issues regarding LTBI screening of immigrants and urban risk groups, including cost-effectiveness [10], have been published elsewhere. Screening for LTBI should be risk-based and not population-based $[110,111]$. Priority for LTBI screening in EU countries is usually given to recent contacts, children, immunocompromised patients and healthcare workers [112].

\section{Latent tuberculosis infection and big cities}

Recent immigrants, who are usually overrepresented in big cities, and urban risk groups for TB are often screened for TB disease $[16,17,77,113]$. Testing for LTBI is less frequently reported $[6,76]$. Screening of immigrants for LTBI can be cost-effective depending on preventive treatment completion $[10,81,114]$ but is often poorly implemented [115] and the expected reduction of TB incidence has been questioned [116]. Immigrant screening can be performed in primary care settings in big cities $[58,59]$ and this location has been reported to be acceptable to the immigrant population [117]. The management of LTBI in urban risk groups such as homeless people or people with drug misuse is controversial. Although the prevalence of LTBI is likely to be higher than in the general population, screening opportunities are limited by the hard-to-reach and hard-totreat characteristics of these subgroups. Additionally, drug and alcohol misuse and co-infection with HIV or other blood-borne viruses increase the probability of adverse reactions to preventive treatment $[10,13]$.
Identification of active TB among homeless people was found to be more important [118]. The prevalence of LTBI upon detention in European prisons can be high, but diagnosis of TB disease usually remains the priority $[119,120]$. Novel approaches to improve preventive treatment completion in deprived populations, such as shorter or simpler regimens, are urgently needed, and should be implemented as they have been in the United States $[10,121,122]$.

\section{Recommendations}

Big city TB control programmes should

6.1. offer LTBI screening to urban risk groups only when an effective programme exists for active case finding and holding in these groups;

6.2. offer LTBI screening according to national guidelines, accompanied by a clear plan on preventive treatment;

6.3. organise a risk-based approach to LTBI screening, prioritising people who are at highest risk of infection or progression $[63,78,112,123]$.

\section{DNA fingerprinting}

\section{General background}

Recent advances in molecular biology have provided new tools to better comprehend the epidemiology and transmission of TB disease. Mycobacterium tuberculosis strain genotyping or DNA fingerprinting has been widely used in population-based studies to determine the extent of ongoing TB transmission and risk factors in various communities $[124,125]$. Insights and applications of DNA fingerprinting in TB control have been described in review articles [126-128]. In the ECDC follow-up to the EU Action Plan to fight TB, genotyping of $M$. tuberculosis was proposed as a useful way of systematically monitoring disease transmission [129].

\section{DNA fingerprinting and big cities}

The contribution of DNA fingerprinting to conventional epidemiological data in the context of urban TB control has been described elsewhere [125]. Briefly, molecular indications for epidemiological links and identification of risk factors for transmission are crucial for understanding the specific epidemiology of TB in big cities, allowing the detection of risk groups and informing (targeted) public health interventions $[13,16]$. Urban TB cases are more often seen in foreignborn patients than cases in rural areas because of the higher proportion of migrant population in these cities. Most of these cases have a reactivation of an infection acquired in the patient's native country [26] However, DNA fingerprinting has revealed that in urban migrant cases, transmission is frequently also recent, more often than in non-urban migrant cases [24]. Molecular epidemiological studies identified factors for a higher risk of clustering, reflecting the risk of infection, such as alcohol or intravenous drug misuse, homelessness, or certain ethnic backgrounds [125]. They also confirmed high-risk sites for TB transmission in big cities, including congregate settings such as shelters for 
homeless people or prisons. Fingerprinting can also support extension of outbreak investigations and has been used to monitor trends and evaluate interventions, most specifically in urban areas [130].

\section{Recommendations}

Big city TB control programmes should:

7.1. complement routine surveillance activities and contact tracing with molecular epidemiology to identify unexpected spreading of TB and outbreaks, and to evaluate interventions [125].

\section{General policy, legal framework and organisation of services}

\section{General policy: general background}

Organisation and policies of TB control in the EU have been discussed in review articles covering standards of care [63], contact tracing [78], immigrant screening [77], active case finding [76] and cost-effectiveness [112]. The organisation as well as the legal framework for TB control differs between EU countries. These differences reflect variations in service delivery models, infectious disease law, public health responsibilities, organisation and legal background of screening and the implementation of mandatory isolation [79].

\section{General policy and big cities}

Organisational aspects of big city TB control have recently been described [5]. Lack of central planning, political commitment and mechanisms to commission city-wide services have created barriers to implementation of evidenced-based and cost-effective services for case finding and case holding [17]. Increasing rates of TB have been found where big city TB control systems are fragmented and involve a high number of clinical settings [4,131]. Many of the high-risk TB patients found in big cities have complex social, medical and economic needs, and multi-disciplinary teams, networking, for example, with experts in relevant comorbidities such as HIV and hepatitis $\mathrm{C}$ and community and patient groups and sharing of experience between practitioners, are important in the organisation and provision of care in these settings.

\section{Legal framework general background}

Multiple laws can provide the legal framework for TB control in a country. Infectious disease acts and reports regulate the various responsibilities of national and local authorities, notification or reporting and surveillance of TB or TB-HIV, screening and mandatory isolation in case of threats to public health [132-134]. International legislation (e.g. Universal Declaration of Human Rights European Convention on Human Rights $[135,136])$ state that any application of restrictions, including mandatory isolation, requires (i) a legal basis and (ii) reasonable evidence that the restrictions are necessary to protect public health. The public health argument for compulsory TB screening of immigrants and mandatory isolation is sometimes questioned $[137,138]$.
Legal framework and big cities

A legal framework for notification should provide the information for surveillance, cross-sectional studies and cohort reviews in big cities. [7,98,99] Noncompliant infectious TB patients are common in EU big cites, especially among urban TB risk groups [31]. The use of mandatory isolation is rarely used in some big cities in the EU [139]. Legal frameworks for mandatory isolation can be part of a successful urban TB control programme, if implemented when extensive attempts to support the patient have failed, for example through DOT, incentives and enablers, and social support [16].

\section{Recommendations:}

Big city TB control programmes should:

8.1. be supported by high-level political commitment;

8.2. be organised to ensure accessibility for patients and include sufficient staff and expertise $[4,5,11,80]$;

8.3. promote strong collaboration and coordination between sectors as a prerequisite to ensure delivery of the proposed recommendations;

8.4. have community and patient engagement programmes and address the problem of stigmatisation [58-61];

8.5. use involuntary isolation only as a measure of last resort under humane conditions;

8.6. contribute to a European network to facilitate the exchange of experience between programmes and allowing external assessment.

\section{Strategy, monitoring and evaluation}

\section{General background}

To reach and sustain the goal of eliminating TB in Europe it is fundamental that countries develop strategic TB control plans tailored to their own epidemiological situation. The ECDC Framework Action Plan to fight tuberculosis in the European Union and its followup provides areas for strategy development, including monitoring and evaluation, which can serve as a basis for a country's plan $[28,129]$. Outcome assessment should be supported by robust and quality-assured surveillance and laboratory systems, and linked to molecular epidemiology where possible $[28,129]$. Systematic cohort reviews are of great value to improve the quality of data for every TB case and are key to the evaluation of TB control programmes by identifying problematic issues and gaps in case management $[7,98]$.

\section{Strategy, monitoring and evaluation of TB programmes and big cities}

In countries where there is an identified problem with TB accumulating in vulnerable groups in big cities, the TB control strategy should be adapted to target those specific challenges and needs. Evaluation of big city TB programmes, internal and external, should be performed regularly in order to identify gaps in services and be based upon ECDC-proposed indicators to monitor progress towards elimination [129], such as notification rates (including sputum smear positive 
TB), paediatric TB, diagnostic delay, treatment adherence rates, treatment outcome, cost-effectiveness and social support $[5,17,99]$. High-risk deprived communities as well as civil society can be engaged in such a process. DNA fingerprinting can monitor trends and evaluate interventions, most specifically in urban areas $[16,19,125]$.

\section{Recommendations}

Big city TB control programmes should:

9.1. implement a continuous process of programme evaluation that will inform strategy development and include independent external peer review;

9.2. perform review of case detection and cohort review of case management and treatment outcome. Reviews should include analysis by urban risk group [98, 140];

9.3. collaborate to evaluate targeted interventions in big cities, such as molecular epidemiology, to establish additional benefits in TB control [125].

\section{Conclusion}

In low-incidence EU countries TB is increasingly concentrated in big cities. There is an urgent need for the systematic implementation of effective, cost-effective, evidence-based and innovative approaches and tools to improve early case finding, case holding and treatment completion in metropolitan areas, especially among vulnerable groups [28]. The working group for TB control in big cities and urban risk groups in the EU has formulated 32 recommendations for big city TB control in nine areas of possible interventions. These recommendations resulted from a consensus process, and were prepared as precisely as possible but owing to the consensus approach, some were formulated as considerations. This was necessary because the epidemiological background of TB may differ between big EU cities, some interventions may not be available in all countries and cities, and there are limitations to what the working group can instruct EU Member States to do. Some of the recommendations are not strictly specific to big cities, because there is some overlap between urban TB control and general principles, and therefore the working group agreed not to mention certain issues, such as nosocomial IC, in the recommendations, when it was considered to be a general principle. Overall, this consensus statement demonstrates that at present the level of evidence for these recommendations to achieve control of TB in EU cities and among urban risk groups is limited and should be improved. Exchange of experience, collaborative research, advocacy and cooperation between different urban TB programmes in the EU will be instrumental to achieving TB control.

\section{Conflict of interest}

None declared.

Authors' contributions
The first draft of the manuscript was written by RvH, GdV, RA and IA. All authors contributed to revisions and intellectual content of the paper and have seen and agreed the final version of the manuscript.

\section{References}

1. de Vries G, Aldridge RW, Caylà JA, Haas WH, Sandgren A, van Hest NA, Abubakar I, the Tuberculosis in European Union Big Cities Work. Epidemiology of tuberculosis in big cities of the European Union and European Economic Area countries. Euro Surveill. 2014;19(9):pii=20726.

2. Hayward AC, Darton T, Van-Tam JN, Watson JM, Coker R, Schwoebel V. Epidemiology and control of tuberculosis in Western European cities. Int J Tuberc Lung Dis. 2003;7(8):751-7.

3. Farge D, Porcher R, Antoun F, Fain O, Keshtmand H, Rocher $\mathrm{G}$, et al. Tuberculosis in European cities: establishment of a patient monitoring system over 10 years in Paris, France. Int J Tuberc Lung Dis. 2007;11(9):992-8.

4. Bothamley GH Kruijshaar ME, Kunst H, Woltmann G, Cotton M, Saralaya D, et al. Tuberculosis in UK cities: workload and effectiveness of tuberculosis control programmes. BMC Public Health. 2011;11:896. http://dx.doi. org/10.1186/1471-2458-11-896

5. Caylà JA, Orcau A. The control of tuberculosis in large cities in developed countries; an organisational problem. BMC Med. 2011;9:127. http://dx.doi.org/10.1186/1741-7015-9-127

6. Solsona J, Caylà JA, Nadal J, Bedia M, Mata C, Brau J, et al. Screening for tuberculosis upon admission to shelters and free-meal services. Eur J Epidemiol. 2001;17(2):123-8. http:// dx.doi.org/10.1023/A:1017580329538

7. Story A, Murad S, Roberts W, Verheyen M, Hayward AC. Tuberculosis in London: the importance of homelessness, problem drug use and prison. Thorax. 2007;62(8):667-71. http://dx.doi.org/10.1136/thx.2006.065409

8. Abubakar I, Crofts IP, Gelb D, Story A, Andrews N, Watson JM. Investigating urban-rural disparities in tuberculosis treatment outcome in England and Wales. Epidemiol Infect. 2008;136(1):122-7. http://dx.doi.org/10.1017/ So950268807008333

9. Kruijshaar ME, Abubakar I, Dedicoat M, Bothamley GH, Maguire H, Moore J, et al. Evidence for a national problem: continued rise in tuberculosis case numbers in urban areas outside London. Thorax. 2012;67(3):275-7. http://dx.doi. org/10.1136/thoraxjnl-2011-200850

10. Abubakar I, Stagg HR, Cohen T, Mangtani P, Rodrigues LC, Pimpin L, et al. Controversies and unresolved issues in tuberculosis prevention and control: a low-burden-country perspective. J Infect Dis. 2012;205 Suppl 2:S293-300. http:// dx.doi.org/10.1093/infdis/jir886

11. National Institute for Health and Clinical Excellence (NICE) NICE public health guidance 37: identifying and managing tuberculosis among hard-to-reach groups. London: NICE; 2012. Available from: http://publications.nice.org.uk/ identifying-and-managing-tuberculosis-among-hard-to-reachgroups-ph37

12. van Hest NA, de Vries G, van Gerven PJ, Baars HW. [Delay in the diagnosis of tuberculosis]. Ned Tijdschr Geneeskd. 2003;147(38):1825-9. Dutch.

13. de Vries G, van Hest RA. From contact investigation to tuberculosis screening of drug addicts and homeless persons in Rotterdam. Eur J Public Health. 2006;16(2):133-6. http:// dx.doi.org/10.1093/eurpub/cki203

14. Faustini A, Hall AJ, Perucci CA. Tuberculosis treatment outcomes in Europe: a systematic review. Eur Respir J. 2005;26(3):503-10. http://dx.doi.org/10.1183/09031936.05. 00103504

15. Caylà JA, Rodrigo T, Ruiz-Manzano J, Caminero JA, Vidal $\mathrm{R}$, García JM, et al. Tuberculosis treatment adherence and fatality in Spain. Respir Res. 2009;10:121. http://dx.doi. org/10.1186/1465-9921-10-121

16. de Vries G, van Hest RA, Richardus JH. Impact of mobile radiographic screening on tuberculosis among drug users and homeless persons. Am J Respir Crit Care Med. 2007;176(2):201-7. http://dx.doi.org/10.1164/ rccm.200612-18770C

17. Jit J, Stagg H, Aldridge R, White P, Abubakar I. Dedicated outreach service for hard to reach patients with tuberculosis in London: observational study and economic evaluation. BMJ. 2011;343:d5376. http://dx.doi.org/10.1136/bmj.d5376

18. Goetsch U, Bellinger OK, Buettel KL, Gottschalk R. Tuberculosis among drug users and homeless persons: 
impact of voluntary X-ray investigation on active case finding. Infection. 2012;40(4):389-95. doi 10.007/S15010-011-0238-x.

19. Bernard C, Sougakoff W, Fournier A, Larnaudie S, Antoun F, Robert J, et al. Impact of a 14-year screening programme on tuberculosis transmission among the homeless in Paris. Int J Tuberc Lung Dis. 2012;16(5):649-55.

20. Hall J, Bethell S, Helleren S, Story A, Lipman M. Evaluation of TB peer educators-essential partners in metropolitan TB control. Thorax. 2010; 65: A5 doi:10.1136/thx.2010.150912.4. Available from: http://thorax.bmj.com/content/65/ Suppl 4/A5.2.full.pdf+html. http://dx.doi.org/10.1136/ thx.2010.150912.4

21. Ospina JE, Orcau A, Millet JP, Sánchez F, Casals M, Caylà JA. Community health workers improve contact tracing among immigrants with tuberculosis in Barcelona. BMC Public Health. 2012;12:158 doi:10.1186/1471-2458-12-158. http:// dx.doi.org/10.1186/1471-2458-12-158

22. Person AK, Blain ML, Jiang H, Rasmussen PW, Stout JE. Text messaging for enhancement of testing and treatment for tuberculosis, human immunodeficiency virus, and syphilis: a survey of attitudes toward cellular phones and healthcare. Telemed J E Health. 2011;17(3):185-9. http://dx.doi. org/10.1089/tmj.2010.0164

23. Krueger K, Ruby D, Cooley P, Montoya B, Exarchos A, Djojonegoro BM, et al. Videophone utilization as an alternative to directly observed therapy for tuberculosis. Int J Tuberc Lung Dis. 2010;14(6):779-81.

24. de Vries G, van Hest NA, Baars HW, Sebek MM, Richardus JH. Factors associated with the high tuberculosis case rate in an urban area. Int J Tuberc Lung Dis. 2010;14(7):859-65.

25. van Deutekom H, Gerritsen JJ, van Soolingen D, van Ameijden EJ, van Embden JD, Coutinho RA. A molecular epidemiological approach to studying the transmission of tuberculosis in Amsterdam. Clin Infec Dis. 1997;25(5):1071-7. http://dx.doi. org/10.1086/516072

26. Dahle UR, Eldholm V, Winje BA, Mannsåker T, Heldal E. Impact of immigration on the molecular epidemiology of Mycobacterium tuberculosis in a low-incidence country. Am J Respir Crit Care Med. 2007;176(9):930-5. http://dx.doi. org/10.1164/rccm.200702-1870C

27. Solsona J, Caylà JA, Verdú E, Estrada MP, Garcia S, Roca $D$, et al. Molecular and conventional epidemiology of tuberculosis in an inner city district. Int J Tuberc Lung Dis. 2001;5(8):724-31.

28. European Centre for Disease Prevention and Control (ECDC). Framework Action Plan to fight tuberculosis in the European Union. Stockholm: ECDC; 2008.

29. Quabeck L, Abubakar I, Antoine D, Bergren I, Erkens C, Indra $A$, et al. Comparative analysis of tuberculosis epidemiology in capitals and countries in the west/EU-EuroTB region. Abstract book of the 5 th Congress of the International Union against Tuberculosis and Lung Disease; 2009 May 27 - 30; Dubrovnik, Croatia: p. 57.

30. Veen J, Migliori GB, Raviglione M, Rieder HL, Dara $M$, Falzon D, et al. Harmonisation of TB control in the WHO European region: the history of the Wolfheze Workshops. Eur Respir J. 2011;37(4):950-9. http://dx.doi. org/10.1183/09031936.00019410

31. Story A. Epidemiology and control of tuberculosis in hard to reach groups in London. [academic thesis]. Amsterdam: University of Amsterdam; 2012.

32. Harbour R, Miller J. A new system for grading recommendations in evidence based guidelines. BMJ. 2001;323(7308):334-6 http://dx.doi.org/10.1136/ bmj.323.7308.334

33. European Centre for Disease Prevention and Control/WHO Regional Office for Europe. Tuberculosis surveillance and monitoring in Europe 2012. Stockholm: European Centre for Disease Prevention and Control, 2012. Available from: http:// ecdc.europa.eu/en/publications/publications/1203-annualtb-report.pdf

34. Semenza JC. Strategies to intervene on social determinants of infectious diseases. Euro Surveill. 2010;15(27):pii=19611.

35. Semenza JC, Giesecke J. Intervening to reduce inequalities in infections in Europe. Am J Public Health. 2008;98(5):787-92. http://dx.doi.org/10.2105/AJPH.2007.120329

36. Suk J, Manissero D, Buscher G, Semenza JC. Wealth inequality and TB elimination in Europe. Emerg Infect Dis. 2009;15(11):1812-4. http://dx.doi.org/10.3201/eid1511.090916

37. Ploubidis GB, Palmer MJ, Blackmore C, Lim TA, Manissero D, Sandgren A, et al. Social determinants of tuberculosis in Europe: a prospective ecological study. Eur Respir J. 2012;40(4):925-30 http://dx.doi. org/10.1183/09031936.00184011
38. Álvarez JL, Kunst AE, Leinsalu M, Bopp M, Strand BH, Menvielle G, et al. Educational inequalities in TB mortality in sixteen European populations. Int J Tuberc Lung Dis. 2011;15(11):1461-7. http://dx.doi.org/10.5588/ijtld.10.0252

39. van der Werf M, Giesecke J, Sprenger M. Can the economic crisis have an impact on tuberculosis in the EU/EEA? Euro Surveill. 2012;17(12):pii=20122.

40. Hargreaves JR, Boccia D, Evans CA, Adato M, Petticrew M, Porter JD. The social determinant of TB: from evidence to action. Am J Public Health. 2011;101(4):654-62. http://dx.doi. org/10.2105/AJPH.2010.199505

41. Oren E, Koepsell T, Leroux BG, Mayer J. Area-based socioeconomic disadvantage and tuberculosis incidence. Int J Tuberc Lung Dis. 2012;16(7):880-5. http://dx.doi. org/10.5588/ijtld.11.0700

42. Mangtani P, Jolley DJ, Watson JM, Rodrigues LC. Socioeconomic deprivation and notification rates for tuberculosis in London during 1982-91. BMJ. 1995;310(6985):963-6. http://dx.doi.org/10.1136/ bmj.310.6985.963

43. Bhatti N, Law MR, Morris JK, Halliday R, Moore-Gillon J. Increasing incidence of TB in England and Wales: a study of the likely causes. BMJ. 1995;310(6985):967-9. http://dx.doi. org/10.1136/bmj.310.6985.967

44. Baker M, Das D, Venugopal K, Howden-Chapman P. Tuberculosis associated with household crowding in a developed country. I Epidemiol Community Health. 2008;62(8):715-21. http://dx.doi.org/10.1136/ jech.2007.063610

45. Story A, van Hest R, Hayward A. Tuberculosis and social exclusion. BMJ. 2006;333(7558):57-8. http://dx.doi. org/10.1136/bmj.333.7558.57

46. Craig GM, Booth H, Story A, Hayward A, Hall J, Goodburn $A$, et al. The impact of social factors on tuberculosis management. J Adv Nurs. 2007;58(5):418-24. http://dx.doi. org/10.1111/j.1365-2648.2007.04257.x

47. Craig GM, Booth H, Hall J, Story A, Hayward A, Goodburn A, et al. Establishing a new service role in tuberculosis care: the tuberculosis link worker. J Adv Nurs. 2008;61(4):413-24. http://dx.doi.org/10.1111/j.1365-2648.2007.04498.x

48. Story A, Slockers M, Arrazola de Onate W, Hewett N, van Hest R. Homeless Health Services, Tuberculosis and Economic Crisis: A Tale of Three Cities. Homeless in Europe: Spring 2011. [Accessed 9 June 2012] Available from: http://feantsa. horus.be/files/freshstart/Communications/Homeless $\% 20$ in\%20Europe\%20EN/PDF_2011/Homeless_in_Europe_ Spring_2011.pdf

49. LoBue PA, Cass R, Lobo D, Moser K, Catanzaro A. Development of housing programs to aid in the treatment of tuberculosis in homeless individuals: a pilot study. Chest. 1999;115(1):218-23. http://dx.doi.org/10.1378/chest.115.1.218

50. Díez E, Clavería J, Serra T, Caylà JA, Jansà JM, Pedro R, et al. Evaluation of a social health intervention among homeless tuberculosis patients. Tuber Lung Dis. 1996;77(5):420-4. http://dx.doi.org/10.1016/So962-8479(96)90114-8

51. Tulsky JP, Pilote L, Hahn JA, Zolopa, AJ, Burke M, Chesney M, et al. Adherence to isoniazid prophylaxis in the homeless: a randomized controlled trial. Arch Intern Med. 2000; 16o(5):697-702. http://dx.doi.org/10.1001/archinte.160.5.697

52. Heldal E, Kuyvenhoven JV, Wares F, Migliori GB, Ditiu L, Fernandez de la Hoz K, et al. Diagnosis and treatment of tuberculosis in undocumented migrants in low- or intermediate-incidence countries. Int J Tuberc Lung Dis. 2008;12(8):878-88.

53. Harstad I, Heldal E, Steinshamn SL, Garåsen H, Jacobsen GW. Tuberculosis screening and follow-up of asylum seekers in Norway: a cohort study. BMC Public Health. 2009:14;9:141.

54. Dara M, de Colombani P, Petrova-Benedict R, Centis R, Zellweger JP, Sandgren A, et al. Minimum package for crossborder TB control and care in the WHO European Region: a Wolfheze consensus statement. Eur Respir J. 2012 40(5):10811090. http://dx.doi.org/10.1183/09031936.00053012

55. Roy A, Abubakar I, Chapman A, Andrews N, Pattinson M, Lipman $M$, et al. A controlled trial of the knowledge impact of TB information leaflets among staff supporting substance misusers: pilot study. PLoS One. 2011;6(6):e20875. http:// dx.doi.org/10.1371/journal.pone.0020875

56. Roy A, Abubakar I, Yates S, Chapman A, Lipman M, Monk $P$, Catchpole $M$, et al. Evaluating knowledge gain from TB leaflets for prison and homeless sector staff: the National Knowledge Service TB pilot. Eur J Public Health. 2008;18(6):600-3. http://dx.doi.org/10.1093/eurpub/ckno96

57. Department of Health. Stopping TB in England: Chief Medical Officer's Action Plan. London, Department of Health, 2004. Available from: http://webarchive.nationalarchives.gov. 
uk/20130107105354/http:/www.dh.gov.uk/prod_consum_dh/ groups/dh_digitalassets/@dh/@en/documents/digitalasset/ dh_4100860.pdf

58. Griffiths C, Sturdy P, Brewin P, Bothamley G, Eldridge $S$, Martineau A, et al. Educational outreach to promote screening for TB in primary care: a cluster randomised controlled trial. Lancet. 2007;369 (9572):1528-34. http:// dx.doi.org/10.1016/S0140-6736(07)60707-7

59. Bothamley GH, Rowan JP, Griffiths CJ, Beeks M, McDonald $M$, Beasley $E$, et al. Screening for TB: the port of arrival scheme compared with screening in general practice and the homeless. Thorax. 2002;57(1):45-49. http://dx.doi. org/10.1136/thorax.57.1.45

6o. Nnoaham KE, Pool R, Bothamley G, Grant AD. Perceptions and experiences of TB among African patients attending a TB clinic in London. Int J Tuberc Lung Dis. 2006;10(9):1013-7.

61. Nkulu FK, Hurtig AK, Ahlm C, Krantz I. Screening migrants for TB - a missed opportunity for improving knowledge and attitudes in high-risk groups: A crosssectional study of Swedish-language students in Umeå, Sweden. BMC Public Health. 2010;10:349. http://dx.doi. org/10.1186/1471-2458-10-349

62. Roy A, Anaraki S, Hardelid P, Catchpole M, Rodrigues LC, Lipman M, et al. Universal HIV testing in London tuberculosis clinics: cluster randomised controlled trial. Eur Respir J. 2013;41(3):627-34. http://dx.doi. org/10.1183/09031936.00034912

63. Migliori GB, Zellweger JP, Abubakar I, Ibraim E, Caminero JA, De Vries G, et al. European union standards for tuberculosis care. Eur Respir J. 2012;39(4):807-19. http://dx.doi. org/10.1183/09031936.00203811

64. Sotgiu G, D'Ambrosio L, Centis R, Bothamley G, Cirillo DM, De Lorenzo S, et al. TB and M/XDR-TB infection control in European TB reference centres: the Achilles heel? Eur Respir J. 2011;38(5):1221-3. http://dx.doi. org/10.1183/09031936.00029311

65. Paolo WF Jr, Nosanchuk JD. TB in New York City: recent lessons and a look ahead. Lancet Infect Dis. 2004;4(5):28793. http://dx.doi.org/10.1016/S1473-3099(04)01004-7

66. Dharmadhikari AS, Mphahlele M, Stoltz A, Venter K, Mathebula R, Masotla T, et al. Surgical face masks worn by multidrug-resistant tuberculosis patients: Impact on infectivity of air on a hospital ward. Am. J Respir Med Crit Care. 2012;185(10):1104-9. http://dx.doi.org/10.1164/ rccm.201107-11900C

67. Lemaître N, Sougakoff W, Truffot-Pernot C, Cambau E, Derenne IP, Bricaire $F$, et al. Use of DNA fingerprinting for primary surveillance of nosocomial tuberculosis in a large urban hospital: detection of outbreaks in homeless people and migrant workers. Int J Tuberc Lung Dis. 1998;2(5):390-6.

68. Hannan MM, Peres H, Maltez F, Hayward AC, Machado J, Morgado A, Proenca R, et al. Investigation and control of a large outbreak of multi-drug resistant tuberculosis at a central Lisbon hospital. J Hosp Infect. 2001;47(2):91-7. http:// dx.doi.org/10.1053/jhin.2000.0884

69. Moro ML, Errante I, Infuso A, Sodano L, Gori A, Orcese CA, et al. Effectiveness of infection control measures in controlling a nosocomial outbreak of multidrug-resistant tuberculosis among HIV patients in Italy. Int J Tuberc Lung Dis. 2000;4(1):61-8.

70. Couceiro L, Santana P, Nunes C. Pulmonary tuberculosis and risk factors in Portugal: a spatial analysis. Int J Tuberc Lung Dis. 2011;15(11):1445-54. http://dx.doi.org/10.5588/ ijtld.10.0302

71. Diel R, Meywald-Walter K, Gottschalk R, Rüsch-Gerdes S, Niemann S. Ongoing outbreak of tuberculosis in a low-incidence community: a molecular-epidemiological evaluation. Int J Tuberc Lung Dis. 2004;8(7):855-61.

72. Lukacs J, Tubak V, Mester J, Dávid S, Bártfai Z, Kubica T, et al. Conventional and molecular epidemiology of tuberculosis in homeless patients in Budapest, Hungary. J Clin Microbiol. 2004;42(12):5931-4. http://dx.doi.org/10.1128/ JCM.42.12.5931-5934.2004

73. Valin N, Antoun F, Chouaïd C, Renard M, Dautzenberg B, Lalande V, et al. Outbreak of tuberculosis in a migrant's shelter, Paris, France, 2002. Int J Tuberc Lung Dis. 2005;9(5):528-33.

74. Ködmön C, Niemann S, Gutierrez MC, Sola C, Rastogi N, Lukács J, et al. Molecular clues of a microepidemy among homeless tuberculosis patients in Budapest due to a new and local Mycobacterium tuberculosis clade. Infect Genet Evol. 2007;7(5): 632-5. http://dx.doi.org/10.1016/j. meegid.2007.06.003

75. Fernandez de la Hoz K, Inigo J, Fernandez-Martin JI, Arce A, Alonso-Sanz M, Gomez-Pintado P, et al. The influence of HIV infection and imprisonment on dissemination of
Mycobacterium tuberculosis in a large Spanish city. Int J Tuberc Lung Dis. 2001;5(8):696-702.

76. Bothamley GH, Ditiu L, Migliori GB, Lange C; TBNET contributors. Active case finding of tuberculosis in Europe: a Tuberculosis Network European Trials Group (TBNET) survey. Eur Respir J. 2008;32(4):1023-30. http://dx.doi. org/10.1183/09031936.00011708

77. Klinkenberg E, Manissero D, Semenza JC, Verver S. Migrant tuberculosis screening in the EU/EEA: yield, coverage and limitations. Eur Respir J. 2009;34(5):1180-9. http://dx.doi. org/10.1183/09031936.00038009

78. Erkens CG, Kamphorst M, Abubakar I, Bothamley GH, Chemtob D, Haas W, et al. Tuberculosis contact investigation in low prevalence countries: a European consensus. Eur Respir J. 2010;36(4):925-49. http://dx.doi. org/10.1183/09031936.00201609

79. Coker R, Bell A, Pitman R, Zellweger JP, Heldal E, Hayward $A$, et al. Tuberculosis screening in migrants in selected European countries shows wide disparities. Eur Respir J. 2006;27(4):801-7. http://dx.doi.org/10.1183/09031936.06.0 0104305

8o. van Hest R, Story A. Tuberculosis control among homeless persons in the European Union: more than words alone. ENHW Newsletter. 2008;6:4-7. Available from: http://www. feantsa.org/spip.php?article387\&lang=en .

81. National Institute for Health and Clinical Excellence (NICE). NICE clinical guideline 117 TB: clinical diagnosis and management of TB, and measures for its prevention and control. London; NICE;, 2011. Available from: http:// publications.nice.org.uk/tuberculosis-cg117

82. Dasgupta K, Menzies D. Cost-effectiveness of tuberculosis control strategies among immigrants and refugees. Eur Respir J. 2005;25(6):1107-16. http://dx.doi.org/10.1183/09031 936.05 .00074004

83. Jones TF, Schaffner W. Miniature chest radiograph screening for tuberculosis in jails: a cost-effectiveness analysis. Am J Respir Crit Care Med. 2001;164(1):77-81. http://dx.doi. org/10.1164/ajrccm.164.1.2010108

84. Erkens C, Slump E, Kamphorst M, Keizer S, van Gerven PJ, Bwire R, et al. Coverage and yield of entry and follow-up screening for tuberculosis among new immigrants. Eur Respir J. 2008;32(1):153-61. http://dx.doi. org/10.1183/09031936.00137907

85. Southern A, Premaratne N, English M, Balzs J, O'Sullivan D. Tuberculosis among homeless people in London: an effective model of screening and treatment. Int J Tuberc Lung Dis. 1999;3(11):1001-8

86. van Hest NA, De Vries G, Smit F, Grant AD, Richardus JH. Estimating the coverage of a targeted mobile tuberculosis screening programme among illicit drug users and homeless persons with truncated models. Epidemiol Infect. 2008;136(5):628-35. http://dx.doi.org/10.1017/ So950268807009235

87. Kmietowicz Z. NICE advises screening for TB in hostels and prisons to reduce UK cases. BMJ. 2012;344: e2309. doi: 10.1136/bmj.e2309. http://dx.doi.org/10.1136/bmj.e2309

88. European Centre for Disease Prevention and Control (ECDC) and European Monitoring Centre for Drugs and Drug Addiction (EMCDDA). Prevention and control of infectious diseases among people who inject drugs. Stockholm: ECDC; 2011. Available from: http://www.emcdda.europa.eu/ publications/ecdc-emcdda-guidance

89. Mulder C, Klinkenberg E, Manissero D. Effectiveness of tuberculosis contact tracing among migrants and the foreign born population. Euro Surveill 2009;14(11):pii=19153.

90. Fox GJ, Dobler CC, Marks GB. Active case finding in contacts of people with tuberculosis. Cochrane Database Syst Rev. 2011;(9):CDo08477.

91. Mulder C, van Deutekom H, Huisman EM, Meijer-Veldman W, Erkens CG, van Rest J, et al. Coverage and yield of tuberculosis contact investigations in the Netherlands. Int J Tuberc Lung Dis. 2011;15(12):1630-7. http://dx.doi. org/10.5588/ijtld.11.0027

92. Balasegaram S, Grant R, Ormerod P, Mant J, Hayward J, Lowe $\mathrm{D}$, et al. A survey of tuberculosis clinic provision in England and Wales. Public Health. 2008;122(6):602-12. http://dx.doi. org/10.1016/j.puhe.2007.09.015

93. New York City Department of Health and Mental Hygiene (NYCDH). Annual Summary 2008: New York City is Stopping TB. New York: NYCDH; 2009. Available from: http://www.nyc. gov/html/doh/downloads/pdf/tb/tb_annualsummaryo8.pdf

94. Pop-Eleches C, Thirumurthy H, Habyarimana JP, Zivin JG, Goldstein MP, de Walque D, et al. Mobile phone technologies improve adherence to antiretroviral treatment in a resource limited setting: a randomised controlled trial of text 
message reminders. AIDS. 2011;25(6):825-34. http://dx.doi. org/10.1097/QAD.obo13e32834380c1

95. Van den Boogaard J, Lyimo RA, Boeree MJ, Kibiki GS, Aarnoutse RE. Electronic monitoring of treatment adherence and validation of alternative adherence measures in tuberculosis patients: a pilot study. Bull World Health Organ. 2011;89(9):632-9. http://dx.doi.org/10.2471/BLT.11.086462

96. Magis-Escurra C, Miedema JR, de Lange WC, van Ingen J, Dekhuijzen PN, Boeree MJ. [Characteristics and treatment of tuberculosis patients in Dekkerswald, 2000-2005]. Ned Tijdschr Geneeskd. 2008;152(11):622-6. Dutch.

97. Geerligs WA, Van Altena R, De Lange WCM, Van Soolingen D, Van Der Werf TS. Multidrug-resistant tuberculosis: long-term treatment outcome in the Netherlands. Int J Tuberc Lung Dis. 2000;4(8):758-64.

98. Munsiff SS, Ahuja SD, King L, Udeagu CC, Dorsinville M, Frieden TR, et al. Ensuring accountability: the contribution of the cohort review method to tuberculosis control in New York City. Int J Tuberc Lung Dis. 2006;10(10):1133-9.

99. Rodrigo T, Caylà JA, Galdós-Tangüis H, García de Olalla P, Brugal MT, Jansà JM. Proposing indicators for evaluation of tuberculosis control programmes in large cities based on the experience of Barcelona. Int J Tuberc Lung Dis. 2001;5(5):432-40.

100. D'Lugoff MI, Jones W, Kub J, Glass N, Thompson D, BrinkleyLaughon S, et al. Tuberculosis screening in an at-risk immigrant Hispanic population in Baltimore city: an academic health center/local health department partnership. J Cult Divers. 2002;9(3):79-85.

101. Anderson C, Story A, Brown T, Drobniewski F, Abubakar I. Tuberculosis in UK prisoners: a challenge for control. J Epidemiol Community Health. 2010;64(4):373-6. http:// dx.doi.org/10.1136/jech.2009.094375

102. Roberts CA, Lobato MN, Bazerman LB, Kling R, Reichard $A A$, Hammett TM. Tuberculosis prevention and control in large jails: a challenge to tuberculosis elimination. Am Prev Med. 2006;30(2):125-30. http://dx.doi.org/10.1016/j. amepre.2005.10.018

103. Nutini S, Fiorenti F, Codecasa LR, Casali L, Besozzi G, Di Pisa G, et al. Hospital admission policy for tuberculosis in pulmonary centres in Italy: a national survey. AIPO Tuberculosis Study Group. Italian Association of Hospital Pulmonologists. Int J Tuberc Lung Dis. 1999;3(11):985-91.

104. Thomas JA, Laraque F, Munsiff S, Piatek A, Harris TG. Hospitalizations for tuberculosis in New York City: how many could be avoided? Int J Tuberc Lung Dis. 2010;14(12):1603-12.

105. Royal College of Nursing. Tuberculosis case management and cohort review. Guidance for health professionals. London: Royal College Nursing; 2012. Available from: https://www. rcn.org.uk/_data/assets/pdf_file/0010/439129/004204.pdf

106. Volmink J, Garner P. Directly observed therapy for treating tuberculosis. Cochrane Database Syst Rev. 2007;(4):CDo03343.

107. Brent Refugee Forum. Knowledge, perceptions and barriers and the social meaning of tuberculosis among asylum seekers, homeless people and refugee communities in Brent 2004-2006. London: Brent Refugee Forum; 2007.

108. Belling R, Woods L, Boudioni M, McLaren S. Pan London Tuberculosis services: An audit evaluation. Institute for Strategic Leadership and Improvement. London: London South Bank University; 2008.

109. European Centre for Disease Prevention and Control (ECDC). Use of interferon-gamma release assays in support of TB diagnosis. Stockholm: ECDC; 2011. Available from: http:/ ecdc.europa.eu/en/publications/publications/1103_gui_igra. pdf

110. Miller TL, Hilsenrath P, Lykens K, McNabb SJ, Moonan PK, Weis $\mathrm{SE}$. Using cost and health impacts to prioritize the targeted testing of tuberculosis in the United States. Ann Epidemiol. 2006;16(4):305-12. http://dx.doi.org/10.1016/j. annepidem.2005.07.053

111. Moonan PK, Oppong J, Sahbazian B, Singh KP, Sandhu $R$, Drewyer $G$, et al. What is the outcome of targeted tuberculosis screening based on universal genotyping and location? Am J Respir Crit Care Med. 2006;174(5):599-604. http://dx.doi.org/10.1164/rccm.200512-19770C

112. Nienhaus A, Schablon A, Costa JT, Diel R. Systematic review of cost and cost-effectiveness of different TB-screening strategies. BMC Health Serv Res. 2011;11:247. http://dx.doi. org/10.1186/1472-6963-11-247

113. Verver S, Bwire R, Borgdorff MW. Screening for pulmonary TB among immigrants: estimated effect on severity of disease and duration of infectiousness. Int J Tuberc Lung Dis. 2001;5(5):419-25.
114. Pareek M, Watson JP, Ormerod LP, Kon OM, Woltmann $G$, White PJ, et al. Screening of immigrants in the UK for imported latent tuberculosis: a multicentre cohort study and cost-effectiveness analysis. Lancet Infect Dis. 2011;11(6):43544. http://dx.doi.org/10.1016/S1473-3099(11)70069-X

115. Pareek M, Abubakar I, White PJ, Garnett GP, Lalvani A. Tuberculosis screening of migrants to low-burden nations: insights from evaluation of UK practice. Eur Respir J. 2011;37(5):1175-82. http://dx.doi. org/10.1183/09031936.00105810

116. Mandalakas AM, Menzies D. Is screening immigrants for latent tuberculosis cost-effective? Lancet Infect Dis. 2011;11(6):418-9. http://dx.doi.org/10.1016/ S1473-3099(11)70102-5

117. Brewin P, Jones A, Kelly M, McDonald M, Beasly E, Sturdy P, et al. Is screening for tuberculosis acceptable for immigrants? A qualitative study. J Public Health (Oxf). 2006;28(3):253-60. http://dx.doi.org/10.1093/pubmed/fdlo31

118. Kong PM, Tapy J, Calixto P, Burman WJ, Reves RR, Yang Z, et al. Skin-test screening and tuberculosis transmission among the homeless. Emerg Infect Dis. 2002;8(11):1280-4. http:// dx.doi.org/10.3201/eido811.020306

119. Ritter C, Elger BS. Prevalence of positive tuberculosis skin tests during 5 years of screening in a Swiss remand prison. Int J Tuberc Lung Dis. 2012;16(1):65-9. http://dx.doi. org/10.5588/ijtld.11.0159

120. Marco A, Solé N, Orcau A, Escribano M, del Ba-o L, Quintero $\mathrm{S}$, et al. Prevalence of latent tuberculosis infection in inmates recently incarcerated in a men's prison in Barcelona. Int J Tuberc Lung Dis. 2012;16(1):60-4. http://dx.doi.org/10.5588/ ijtld.11.0007

121. Sterling TR, Villarino ME, Borisov AS, Shang N, Gordin $\mathrm{F}$, Bliven-Sizemore $\mathrm{E}$, et al. Three months of rifapentine and isoniazid for latent tuberculosis infection. N Engl J Med. 2011;365(23):2155-66. http://dx.doi.org/10.1056/ NEJMoa1104875

122. Sharma SK, A, Kadhiravan T, Tharyan P. Rifamycines (rifampicin, rifabutin and rifapentin) compared to isoniazid for preventing tuberculosis in HIV-negative people at risk of active TB. Cochrane Database Syst Rev. 2013;(7):CDo07545.

123. Lange $\mathrm{C}$, Rieder HL. Intention to test is intention to treat. Am J Respir Crit Care Med. 2011;183(1):3-4. http://dx.doi. org/10.1164/rccm.201011-1881ED

124. van Deutekom H. Conventional and molecular epidemiological studies on tuberculosis. [academic thesis]. Amsterdam: University of Amsterdam; 2006.

125. de Vries G. DNA fingerprinting for TB control in a metropolitan area. [academic thesis]. Rotterdam: Erasmus University; 2009.

126. Glynn JR, Bauer J, de Boer AS, Borgdorff MW, Fine PE, Godfrey-Faussett $P$, et al. Interpreting DNA fingerprint clusters of Mycobacterium tuberculosis. European Concerted Action on Molecular Epidemiology and Control of Tuberculosis. Int J Tuberc Lung Dis. 1999;3(12):1055-60.

127. Mathema B, Kurepina NE, Bifani PJ, Kreiswirth BN. Molecular epidemiology of tuberculosis: current insights. Clin Microbiol Rev. 2006;19(4):658-85. http://dx.doi.org/10.1128/ CMR.00061-05

128. Fok A, Numata Y, Schulzer M, Fitzgerald MJ. Risk factors for clustering of tuberculosis cases: a systematic review of population-based molecular epidemiology studies. Int J Tuberc Lung Dis. 2008;12(5):480-92.

129. European Centre for Disease Prevention and Control (ECDC). Progressing towards TB elimination. A follow-up to the Framework Action Plan to Fight Tuberculosis in the European Union. Stockholm: ECDC; 2010. Available from: http:// ecdc.europa.eu/en/publications/publications/101111_spr progressing_towards_tb_elimination.pdf

130. de Vries G, van Hest RA, Burdo CC, van Soolingen D, Richardus JH. A Mycobacterium tuberculosis cluster demonstrating the use of genotyping in urban tuberculosis control. BMC Infect Dis. 2009;9:151. http://dx.doi. org/10.1186/1471-2334-9-151

131. Hayward J, Murray D, Iny I, Jarrett J, Lonergan K, Pillas D, et al (Public Health Action Support Team (PHAST)). London TB Service Review and Health Needs Assessment. London: PHAST; 2010. Available from: https://www.brit-thoracic. org.uk/Portals/o/Clinical\%2olnformation/Tuberculosis/ P263\%20PHAST\%2oLondon\%20TB\%20Project\%20Final\%20 report\%20l.pdf

132. Decree of 27 October 2008 , laying down new requirements regarding public health matters (Public Health Decree). Bulletin of Acts, Orders and Decrees in the Netherlands: 2008; 461. Available from: http://www.ilo.org/wcmsp5/ groups/public/---ed_protect/---protrav/---ilo_aids/ documents/legaldocument/wcms_127978.pdf. 
133. Health Council of the Netherlands. Law on tuberculosis screening among the population. The Hague, Health Council of the Netherlands, 1999.

134. Health Council of the Netherlands: Committee on ethical and legal aspects of tuberculosis control, compulsion and pressure in tuberculosis control. The Hague, Health Council of the Netherlands (1996/07), 1996.

135. General Assembly of the United Nations. The Universal Declaration of Human Rights. 1948. Available from: http:// www.un.org/Overview/rights.htm

136. Council of Europe. European Convention for the Protection of Human Rights and Fundamental Freedoms, as amended by Protocols Nos. 11 and 14. 1950. Available from: http:// conventions.coe.int/treaty/en/treaties/html/005.htm

137. Coker R. Compulsory screening of immigrants for tuberculosis and HIV. BMJ. 2004;328(7435):298-300. http://dx.doi. org/10.1136/bmj.328.7435.298

138. Coker RJ. Public health impact of detention of individuals with tuberculosis: systematic literature review. Public Health. 2003;117(4):281-7. http://dx.doi.org/10.1016/ So033-3506(03)00035-0

139. Coker R. Just coercion? Detention of nonadherent tuberculosis patients. Ann N Y Acad Sci. 2001;953:216-23. http://dx.doi. org/10.1111/j.1749-6632.2001.tb11380.x

140. Veen J, Raviglione M, Rieder HL, Migliori GB, Graf P, Grzemska M, et al. Standardized tuberculosis treatment outcome monitoring in Europe. Recommendations of a Working Group of the World Health Organization (WHO) and the European Region of the International Union against Tuberculosis and Lung Disease (IUATLD) for uniform reporting by cohort analysis of treatment outcome in tuberculosis patients. Eur Respir J. 1998;12(2):505-10. http://dx.doi.org/10 $.1183 / 09031936.98 .12020505$ 